\title{
Produksi Telur dan Reproduksi Ayam Silangan Antara Ayam Merawang dengan Ayam Arab serta Pendugaan Nilai Ripitabilitasnya
}

\section{Egg Production and Reproduction Traits Between Merawang with Arab Chicken Crossing and Repeatability Estimation}

\author{
S. Darwati ${ }^{1 *}$, R. Afnan ${ }^{1}$, H. Nurcahya ${ }^{2}$, dan N. Widayanti ${ }^{1}$ \\ ${ }^{1}$ Departemen Ilmu Produksi dan Teknologi Peternakan, Fakultas Peternakan, \\ Institut Pertanian Bogor, Bogor \\ ${ }^{2}$ Program Studi Biologi, Universitas Nasional, Jakarta \\ *E-mail: darwatisri63@gmail.com \\ (Diterima: 03 Januari 2019; Disetujui: 01 Maret 2019)
}

\begin{abstract}
ABSTRAK
Salah satu ayam lokal Indonesia yang memiliki potensi penghasil telur dan daging atau tipe dwiguna adalah ayam merawang (M) dan ayam lokal petelur adalah ayam arab (A). Persilangan kedua ayam lokal tersebut diharapkan meningkatkan produktivitas ayam lokal. Penelitian ini bertujuan untuk menganalisis performa produksi dan reproduksi persilangan ayam merawang dan arab. Selain itu, menganalisis nilai ripitabilitas sifat produksi dan reproduksi persilangan ayam merawang dan arab. Persilangan yang diamati terdiri dari MAMA, AMA, dan MAA dengan ratio jenis kelamin 1 jantan dengan 2 betina. Pakan yang diberikan adalah $60 \%$ pakan ayam petelur dicampur dengan $40 \%$ dedak padi. Koleksi pengumpulan telur tetas 1 minggu sesuai periode memasukkan ke mesin tetas per minggu. Peubah yang diamati untuk sifat produksi yaitu: bobot telur, indeks telur, produksi telur, konsumsi dan sifat reproduksi yaitu: konversi pakan, fertilitas, daya tetas, serta kematian embrio. Data peubah yang diukur dianalisis ragam dan diduga nilai ripitabilitasnya. Berat telur AMA (48 g) nyata paling berat dibanding MAMA (46 g) dan MAA (38 g) dengan indeks telur 0,77-0,78. Produksi telur berkisar 52,4\%-59,5\%, konsumsi pakan dan konversi pakan tidak berbeda nyata diantara ketiganya. Fertilitas, daya tetas, dan mortalitas embrio tidak berbeda. Nilai ripitabiltas sifat produksi berkisar 0,2-0,8 tergolong sedang hingga tinggi, namun nilai ripitabilitas untuk sifat reproduksi rendah. Dari hasil penelitian ini dapat disimpulkan bahwa persilangan ayam merawang dengan arab memiliki potensi sebagai ayam lokal petelur.
\end{abstract}

Kata kunci: persilangan merawang dengan arab, produksi, reproduksi, ripitabilitas

\section{ABSTRACT}

One of Indonesian native chicken that has the potential to produce eggs and meat or dual-purpose type is merawang chicken (M) and egg layer chicken is Arab chicken (A). The crossing of the two local chickens is expected to increase the productivity of native chickens. This study aimed to analyze the performance of production and reproduction of crosses between merawang and Arab chickens. In addition, analyzing the value of the repeatability of the production and reproduction of merawang and Arab chicken crossing. The cross observed consisted of MAMA, AMA, and MAA with sex ratio 1 male and 2 females. The feed given was $60 \%$ of feed laying hens mixed with 40\% rice bran. Collection of hatching eggs 1 week according to the period of entry into hatching machines every week. The variables observed for production traits were: egg weight, egg index, egg production, consumption and reproduction traits were: feed conversion, fertility, hatchability, and embryo mortality. The variable data measured were analyzed by variance and expected the value of repeatability. Egg weight of AMA (48 g) was the most severe compared to MAMA (46 g) and MAA (38 g) with an egg index of 0.77-0.78. Egg production ranged from $52.4 \%-59.5 \%$, feed consumption, and feed conversion were not significantly different between this cross. Fertility, hatchability and embryo mortality were not different. The repeatability value of the production traits ranged from 0.2-0.8 classified as moderate to high, but the value of repeatability for reproductive traits was low. The conclusion that the 
crossing of merawang and Arab chicken had potential as an egg-producing native chicken.

Keywords: the crossing of merawang and Arab chicken, production, repeatability, reproduction

\section{PENDAHULUAN}

Ayam lokal yang ada di Indonesia beraneka ragam dan kajian yang telah dilakukan oleh peneliti dinyatakan bahwa terdapat 32 rumpun ayam di Indonesia. Ayam lokal tersebut banyak dikembangkan oleh masyarakat baik di pedesaan maupun di perkotaan pada daerah yang subur hingga marginal dengan sistem pemeliharaan yang bervariasi pula yaitu ekstensif, semi intensif, maupun intensif.

Ayam merawang merupakan salah satu jenis ayam lokal dwiguna yang dapat menghasilkan telur dan daging. Adapun ayam arab juga termasuk ayam lokal walaupun bukan ayam asli Indonesia namun telah beradaptasi dan dikembangkan turun temurun di Indonesia. Ayam arab ini dikenal sebagai ayam penghasil telur. Upaya mengkombinasikan kedua potensi yang dimiliki ayam merawang dengan ayam arab untuk meningkatkan mutu genetik ayam lokal adalah melalui persilangan antara kedua ayam tersebut. Berdasarkan kombinasi potensi keduanya maka persilangan antara ayam merawang dan ayam arab diharapkan dapat menghasilkan ayam lokal penghasil telur unggul dengan pertumbuhan yang baik dengan demikian hasil silangannya juga berpotensi sebagai penghasil daging.

Peningkatan produksi telur berkaitan dengan nilai ekonomis suatu peternakan unggas. Adapun performa produksi telur dapat disebabkan oleh faktor genetik maupun non genetik. Selanjutnya untuk menduga kemampuan genetik ternak dapat dilakukan dengan mengetahui nilai ripitabilitas dugaan untuk sifat yang diamati karena nilai ripitabilitas merupakan salah satu parameter genetik untuk mengetahui daya ulang suatu sifat yang dimiliki individu selama individu tersebut hidup.

Ripitabilitas produksi telur pada ayam berkisar dari rendah sampai tinggi yaitu $0,05-$ 0,85 (Udeh, 2010). Besarnya nilai ripitabilitas berkisar antara 0-1 (Noor, 2008). Semakin mendekati angka 1 menunjukkan bahwa ternak tersebut akan mampu mengulang produksi di masa yang akan datang seperti yang telah dicapai saat ini.

Penelitian ini dilakukan untuk mengkaji produktivitas ayam silangan merawang dengan arab dan kemampuan genetik untuk sifat produksi dan reproduksinya. Hasil kajian ini diharapkan bermanfaat untuk pertimbangan pengembangan ayam silangan merawang dengan arab sebagai ayam penghasil telur dan daging yang baik dengan demikian menambah produksi telur dan daging dari ayam lokal.

Penelitian ini bertujuan untuk mengkaji performa produksi dan reproduksi persilangan ayam merawang dan arab. Selain itu, menganalisis kemampuan genetik pada sifat produksi dan reproduksi ayam persilangan antara ayam merawang dan ayam arab melalui pendugaan nilai ripitabiltasnya.

\section{METODE}

\section{Materi}

Sebanyak 18 ekor ayam dewasa hasil persilangan ayam merawang (M) dengan ayam arab (A) digunakan pada penelitian ini. Jenis persilangan meliputi MAMA, MAA, dan AMA.

Ayam ditempatkan di dalam kandang kelompok yang dilengkapi dengan tempat pakan dan tempat air minum. Setiap kandang terdapat 3 ekor ayam dengan perbandingan jantan dan betina yaitu 1:2.

Pakan terdiri dari campuran pakan komersial untuk ayam petelur fase layer dengan dedak padi (Tabel 1). Ratio pakan komersial dengan dedak padi yaitu 60:40. Pakan diberikan sebanyak $100 \mathrm{~g} \mathrm{ekor}^{-1}$ hari $^{-1}$. 
Tabel 1. Kandungan nutrisi pakan pada penelitian

\begin{tabular}{lc}
\hline Nutrisi & Campuran pakan komersial petelur (60\%) dengan dedak padi $(40 \%)$ \\
\hline Abu (\%) & 12,10 \\
Protein kasar (\%) & 14,85 \\
Serat kasar (\%) & 5,77 \\
Lemak kasar (\%) & 3,57 \\
Kalsium (\%) & 1,37 \\
Fosfor (\%) & 0,94 \\
\hline
\end{tabular}

Keterangan: *Analisis pakan dari Laboratorium PAU, Pusat Penelitian Sumberdaya Hayati dan Bioteknologi, Lembaga Penelitian dan Pemberdayaan Masyarakat, IPB (2018)

Tabel 2. Daftar sidik ragam

\begin{tabular}{lcccc}
\hline Sumber Keragaman & $\mathrm{Db}$ & $\mathrm{SS}$ & $\mathrm{MS}$ & EMS \\
\hline Antar individu & $\mathrm{N}-1$ & $\mathrm{SS}_{\mathrm{w}}$ & $\mathrm{MS}_{\mathrm{w}}$ & $\delta_{\varepsilon}^{2}+k \delta_{w}^{2}$ \\
Antar pengukuran dalam individu & $\mathrm{m}-\mathrm{N}$ & $\mathrm{SS}_{\mathrm{e}}$ & $\mathrm{MS}_{\mathrm{e}}$ & $\delta_{\varepsilon}^{2}$ \\
\hline
\end{tabular}

$\mathrm{N}=$ jumlah individu

$\mathrm{m}=$ jumlah total pengukuran

$$
\begin{array}{ll}
\mathrm{k} & =\frac{1}{m-1}\left(m-\frac{\sum m_{k}^{2}}{m}\right) \\
\delta_{\theta}^{2} & =\mathrm{MS}_{\mathrm{e}} \\
\delta_{w}^{2} & =\frac{M S_{w}-M S_{\varepsilon}}{k} \\
\mathrm{R} & =\frac{\delta_{W}^{2}}{\delta_{w}^{2}+\delta_{\varepsilon}^{2}} \\
\mathrm{SE}(\mathrm{R}) & =\sqrt{\frac{2(1-R)^{2}[1+(k-1) R]^{2}}{k(k-1)(N-1)}}
\end{array}
$$

Air minum diberikan ad libitum.

Koleksi telur dilakukan pada pagi dan sore hari. Penimbangan telur dilakukan pada hari tersebut setelah telur dikoleksi untuk memperoleh data bobot telur, indeks telur, dan produksi telur.

Pengamatan sifat reproduksi diperoleh dari hasil penetasan telur. Penetasan didahului dengan koleksi telur tetas dilanjutkan dengan penetasan dengan mesin tetas buatan. Telur tetas yang dimasukkan ke dalam mesin tetas adalah telur hasil koleksi selama 7 hari, dengan demikian periode penetasan berselang 1 minggu setiap periodenya.

Peubah yang diamati meliputi bobot telur, indeks telur, produksi telur, konsumsi pakan, dan konversi pakan untuk performa sifat produksi. Peubah untuk sifat reproduksi meliputi fertilitas, daya tetas, dan mortalitas embrio.

\section{Analisis Data}

Data produksi dan reproduksi dianalisis ragam untuk membandingkan performa dari 3 jenis ayam persilangan, yaitu MAMA, AMA, dan MAA dengan mengacu pada Mattjik dan Sumertajaya (2013). Jika hasil analisis ragam berbeda dilanjutkan dengan uji banding berganda Tukey (Mattjik dan Sumertajaya, 2013).

Nilai ripitabilitas berkisar antara 0-1. Noor (2008) menyatakan bahwa nilai ripitabilitas dapat digolongkan menjadi tiga 
Tabel 3. Produksi persilangan ayam merawang dan ayam arab

\begin{tabular}{lccc}
\hline Sifat & MAMA & AMA & MAA \\
\hline Bobot telur (g) & $46,40 \pm 0,43^{\mathrm{b}}$ & $48,59 \pm 0,66^{\mathrm{a}}$ & $39,14 \pm 0,30^{\mathrm{c}}$ \\
Indeks telur & $0,77 \pm 0,008^{\mathrm{b}}$ & $0,77 \pm 0,003^{\mathrm{b}}$ & $0,80 \pm 0,005^{\mathrm{a}}$ \\
Produksi telur (\%) & $53,37 \pm 21,11$ & $59,52 \pm 5,22$ & $52,38 \pm 12,42$ \\
Konsumsi pakan & $685,96 \pm 19,44$ & $700,00 \pm 0,00$ & $696,89 \pm 4,86$ \\
g ekor $^{-1}$ minggu $\left.^{-1}\right)$ & $5,10 \pm 3,08$ & $3,72 \pm 0,59$ & $6,89 \pm 4,91$ \\
\hline
\end{tabular}

Keterangan: MAMA: merawangarab x merawangarab; AMA: arab x merawangarab; MAA: merawangarab $\mathrm{x}$ arab; superskrip berbeda pada baris yang sama menunjukkan berbeda nyata $(\mathrm{P}<0,05)$

Tabel 4. Reproduksi persilangan ayam merawang dan ayam arab

\begin{tabular}{lccc}
\hline Sifat & MAMA & AMA & MAA \\
\hline Fertilitas (\%) & $98,19 \pm 2,00$ & $99,44 \pm 1,36$ & $100,00 \pm 0,00$ \\
Daya tetas (\%) & $76,70 \pm 6,31$ & $63,39 \pm 17,8$ & $74,97 \pm 11,19$ \\
Mortalitas embrio (\%) & $23,30 \pm 6,31$ & $36,61 \pm 17,81$ & $25,03 \pm 11,19$ \\
\hline
\end{tabular}

Keterangan: MAMA: merawangarab x merawangarab; AMA: arab x merawangarab; MAA: merawangarab $\mathrm{x}$ arab

kategori 0-0,2 (rendah), 0,2-0,4 (sedang) dan lebih dari 0,4 (tinggi). Pada Tabel 2 disajikan analisis statitistik untuk menduga nilai ripitabiltas.

\section{HASIL DAN PEMBAHASAN}

\section{Produksi dan Reproduksi}

Performa produksi dan reproduksi persilangan ayam arab dan merawang diamati pada penelitian ini (Tabel 3). Bobot telur MAMA lebih tinggi dibandingkan MA yaitu $43,423 \pm 4,29 \mathrm{~g}$ pada penelitian terdahulu oleh Darwati et al. (2017) dan keragaman telur MAMA juga lebih rendah dibandingkan MA. Hal ini berarti telur MAMA lebih berat dan seragam dengan demikian memudahkan untuk pengelolaan telurnya baik sebagai telur konsumsi maupun telur tetas.

Bobot telur dari hasil perkawinan interse MA lebih berat dibandingkan bobot telur pada MAA dan AMA. Bobot telur ayam MAMA dan AMA pada penelitian ini lebih tinggi dibandingkan bobot telur ayam merawang dan arab yang dilaporkan Nuraini et al. (2016) dan Suprijatna et al. (2006) bahwa rata-rata bobot telur ayam merawang sebesar 40,42 $\mathrm{g}$ dan ayam arab sebesar 35,30-37,03 g.

Bentuk telur pada persilangan ayam ini memiliki indeks yaitu $0,77-0,80$. Menurut Abidin (2003), bentuk telur tetas normal memiliki kisaran indeks telur 70\%-80\%. Telur pada persilangan ini termasuk kategori normal. Bentuk telur yang normal berarti bahwa telur ayam silangan ini memenuhi kriteria berdasarkan bentuk telurnya sebagai telur tetas.

Produksi telur ketiga jenis ayam silangan pada penelitian ini menunjukkan hasil tidak berbeda nyata $(\mathrm{P}>0,05)$ dengan rataan sebesar $52,38 \%-59,52 \%$ dengan urutan produksi mulai dari yang tinggi yaitu AMA, MAMA, dan MAA. Produksi telur persilangan ini memiliki rataan lebih tinggi dibandingkan dengan Nuraini et al. (2016) dan Suprijatna et al. (2006) yang melaporkan bahwa produktivitas telur ayam merawang sebesar $11,72 \%$ dan ayam arab sebesar 45,62\%-50,69\%.

Konsumsi pakan persilangan ayam arab dan merawang memiliki hasil tidak berbeda nyata $(\mathrm{P}>0,05)$ dengan rataan sebesar 685,96 $-700,00$ g ekor $^{-1}$ minggu $^{-1}$. Hal ini disebabkan 
Tabel 5. Nilai ripitabilitas sifat produksi persilangan ayam merawang dan arab

\begin{tabular}{lccc}
\hline Sifat & MAMA & AMA & MAA \\
\hline Bobot telur & $0,855 \pm 0,052$ & $0,269 \pm 0,113$ & $0,600 \pm 0,100$ \\
Indeks telur & $0,302 \pm 0,123$ & $0,807 \pm 0,059$ & $0,767 \pm 0,070$ \\
Produksi telur & $0,285 \pm 0,119$ & $0,483 \pm 0,111$ & $0,389 \pm 0,115$ \\
Konsumsi pakan & $-0,203 \pm 0,012$ & - & $0,202 \pm 0,109$ \\
Konversi pakan & $0,245 \pm 0,118$ & $0,411 \pm 0,114$ & $0,128 \pm 0,101$ \\
\hline
\end{tabular}

Keterangan: MAMA: merawangarab x merawangarab; AMA: arab x merawangarab; MAA: merawangarab $\mathrm{x}$ arab

Tabel 6. Nilai ripitabilitas sifat reproduksi persilangan ayam merawang dan arab

\begin{tabular}{lccc}
\hline Sifat & MAMA & AMA & MAA \\
\hline Fertilitas & $0,359 \pm 0,125$ & $0,000 \pm 0,077$ & - \\
Daya tetas & $0,545 \pm 0,116$ & $-0,005 \pm 0,075$ & $-0,028 \pm 0,073$ \\
Mortalitas embrio & $0,545 \pm 0,116$ & $-0,005 \pm 0,075$ & $-0,028 \pm 0,073$ \\
\hline
\end{tabular}

Keterangan: MAMA: merawangarab x merawangarab; AMA: arab x merawangarab; MAA: merawangarab $\mathrm{x}$ arab

jumlah pemberian pakan dan temperatur lingkungan dalam penelitian mendekati seragam. Konversi pakan juga menunjukkan tidak berbeda dengan rataan sebesar 3,726,89 , dengan urutan jenis ayam yang efisien adalah AMA, MAMA, dan MAA. Menurut Suprijatna et al. (2006) konversi pakan ayam arab yaitu sebesar 4,79-8,04. Konversi pakan dipengaruhi oleh genetik, mutu pakan, dan temperatur lingkungan (Indra et al., 2013).

Performa reproduksi persilangan ayam MAMA, AMA, dan MAA tidak berbeda nyata $(\mathrm{P}>0,05)$ (Tabel 4). Fertilitas pada persilangan ini berkisar antara 98,19\%-100,00\%. Hasil ini lebih tinggi dibandingkan Astomo et al. (2016) yang melaporkan bahwa telur ayam arab dengan seks rasio jantan dan betina 1:5 memiliki fertilitas $79,17 \%$, sedangkan fertilitas ayam merawang yaitu 95,32\% (Depison, 2006).

Daya tetas pada persilangan ini yaitu $63,39 \%-76,70 \%$. Daya tetas ayam arab 56,25\%-76,67\% (Astomo et al., 2016), sedangkan ayam merawang 79,17\%-95,00\% (Herlina et al., 2016). Hal ini menunjukkan bahwa daya tetas ayam silangan ayam merawang dengan arab berada pada kisaran ayam merawang dan arab.

Mortalitas embrio berbanding terbalik dengan daya tetas. Mortalitas embrio pada ayam persilangan ini yaitu $23,30 \%$ $36,61 \%$. Kematian embrio berkaitan dengan kelembaban dan suhu mesin tetas, serta lama penyimpanan telur tetas (Herlina et al., 2016).

Nilai Ripitabilitas Sifat Produksi dan Reproduksi Ayam Silangan Ayam Merawang dengan Ayam Arab

Ripitabilitas merupakan suatu nilai yang dapat digunakan untuk mengetahui daya ulang suatu sifat yang dimiliki individu selama individu tersebut hidup. Sifat produksi seperti bobot telur, indeks telur, dan produksi telur pada persilangan ayam merawang dan arab memiliki nilai ripitabilitas sedang sampai tinggi (Tabel 5). Bobot telur memiliki nilai ripitabilitasyaitu $0,269-0,855$, berarti berkisar sedang hingga tinggi. Hal ini sesuai dengan nilai ripitabilitas bobot telur pada ayam lain seperti ayam Harco dan Lohman pada penelitian Toye et al. (2012) bahwa nilai ripitabilitas bobot telur adalah 0,41 dan 0,47 . Berarti ayam silangan pada penelitian ini memiliki kemampuan berulang bobot telur dengan performa yang telah dicapai pada

Produksi Telur dan Reproduksi ... (Darwati et al.) 
produksi selanjutnya.

Nilai ripitabilitas produksi telur pada penelitian ini berkisar 0,285-0,483 sedangkan produksi telur diperoleh nilai ripitabilitas 0,22 dan 0,20 pada ayam Harco dan Lohman menurut Toye et al. (2012). Hal ini berarti ayam silangan ini memiliki daya ulang sedang sampai tinggi dan sesuai dengan potensi ayam ras petelur, dengan demikian ayam silangan ini dapat diharapkan untuk dikembangkan sebagai ayam lokal penghasil telur

Nilai ripitabilitas konsumsi dan konversi pakan pada persilangan ayam merawang dan arab rendah sampai sedang yaitu $-0,203$ sampai 0,411 . Konsumsi pakan banyak dipengaruhi oleh lingkungan seperti suhu lingkungan, kualitas, dan kuantitas pakan.

Sifat reproduksi seperti daya tetas dan mortalitas embrio memiliki nilai ripitabilitas rendah yaitu $-0,005$ sampai $-0,028$ pada ayam AMA dan MAA (Tabel 6). Faktor lingkungan seperti suhu dan kelembaban dalam mesin tetas mempengaruhi daya tetas dan kematian embrio. Hal tersebut diduga berdampak pada rendahnya nilai ripitabilitas daya tetas dan kematian embrio walaupun fertilitasnya tinggi.

\section{KESIMPULAN}

Produksi telur ayam silangan MAMA, AMA, dan MAA berkisar 52,85\%-59,5\%, bentuk telur normal dengan berat 46,4; 48,6; dan 39,1 g. Reproduksi ayam silangan baik. Nilai ripitabilitas sifat produksi dan reproduksi persilangan ayam merawang dan arab berkisar dari rendah sampai tinggi.

\section{DAFTAR PUSTAKA}

Abidin, Z. 2003. Membuat dan Mengelola Mesin Tetas Semi Modern. Jakarta: Agromedia Pustaka.

Astomo, W., Septianova, D., dan Kurtini, T. 2016. Pengaruh sex ratio ayam arab terhadap fertilitas, daya tetas, dan bobot tetas. Jurnal Ilmiah Peternakan Terpadu 4(1): 6-12.

Becker, W. A. 1985. Manual of Quantitative Genetics. Ed ke-3. Pullman, Washington: Washington State University.

Darwati, S., Afnan, R., and Maulana, V. S. 2017. Growth of merawang chiken with arab chiken crossing and its reciprocal at 1 to 10 weeks of age. International Seminar on Tropical Animal Production. Yogyakarta: Universitas Gajah Mada. 303-308.

Depison. 2006. Evaluasi hasil persilangan ayam lurik, ayam merawang dan ayam komering. Jurnal Ilmiah Ilmu-Ilmu Peternakan 9(4): 267-276.

Herlina, B., Karyono, T., Novita, R., dan Novantoro, P. 2016. Pengaruh lama penyimpanan telur ayam merawang (Gallus gallus) terhadap daya tetas. Jurnal Sains Peternakan Indonesia 11 (1): 48-57.

Indra, G. K., Achmanu., dan Nurgiartiningsih, A. 2013. Performans produksi ayam arab (Gallus turcicus) berdasarkan warna bulu. J. Ternak Tropika 14(1): 8-14.

Mattjik, A. A dan Sumertajaya, I. M. 2013. Perancangan Percobaan. Cetakan ke-4. Bogor: IPB Pr.

Noor, R. R. 2008. Genetika Ternak. Bogor: Penebar Swadaya.

Nuraini., Hidayat, Z., dan Adrial. 2016. Produksi dan karakteristik telur ayam merawang dengan system pemeliharaan secara intensif di Kebun Percobaan Petaling Kepulauan Bangka Belitung. Prosiding Seminar Nasional Inovasi Teknologi Pertanian. Banjarbaru: BPTP Kalsel. 1108-1114.

Suprijatna, E., Mahfudz, L. D., dan Sarengat, W. 2006. Performans produksi telur ayam arab akibat pemberian ransum berbeda taraf protein saat pertumbuhan. 
Seminar Nasional Teknologi Peternakan dan Veteriner. Semarang: Universitas Diponegoro. 656-662.

Toye, A. A., Sola-Ojo, F. E., and Ayorinde, K. L. 2012. Egg production, egg weight and egg mass repeatability, and genetic gain from use of multiple time-spaced records in Black Harco and Lohman Brown layers. Centrepoint Journal 18 (2) : 147-156.

Udeh, I. 2010. Repeatability of egg number and egg weight in two strains of layer type chicken. International Journal of Poultry Science 9 (7): 675-677. 